JAMP: Jurnal Adminitrasi dan Manajemen Pendidikan

Volume 3 Nomor 3 September 2020, Hal : 216-223

Tersedia Online di http://journal2.um.ac.id/index.php/jamp/

ISSN 2615-8574 (online)

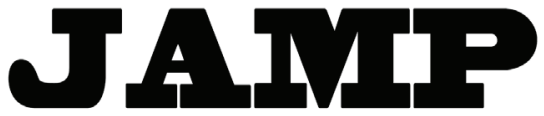

JURNAL ADMINISTRASI DAN MANAJEMEN PENDIDIKAN

\title{
ANALISIS DAMPAK ANJURAN PEMERINTAH TERHADAP BELAJAR DI RUMAH BAGI PELAKU PENDIDIKAN
}

\author{
Laila Nur Alfiah ${ }^{1}$ \\ Deni Ainur Rokhim² \\ Intan Ayu Idha $\mathbf{W}^{3}$ \\ ${ }^{1,3}$ Fakultas Matematika dan Ilmu Pengetahuan Alam, Universitas Negeri Malang \\ ${ }^{2}$ SMA Negeri 3 Sidoarjo \\ laylanuralf@gmail.com,deniainurrokhim@gmail.com
}

\begin{abstract}
The world is experiencing a pandemic of Corona Virus Disease 2019 (Covid-19). The implementation of the Work From Home (WFH) policy has an impact on the closure of educational facilities, so schools are encouraged to study at home or Work From Home (WFH). The application used by teachers to facilitate learning at home through whatsapp in smartphones, raises problems for students who do not have smartphones. This study aims to determine the impact of government policies regarding social restrictions and work at home on educators and students. The method is carried out through surveys using the Google form facility. The results of the study explained that the learning process must be done online or online as recommended by the government, even though the learning process could not be carried out properly due to technical issues such as the use of technology that is still difficult for teachers and constrained internet connections in the learning process. Another impact that is illustrated is that the learning process cannot reach the full learning outcomes both cognitive, affective and psychomotor. The impact of this corona for Education also ultimately requires a greater role of parents in supervision and learning at home..
\end{abstract}

Keywords: Analysis of Government Recommendations; Educational Actors; Corona Virus Disease 2019 (COVID-19; Learning Process; Learning Online

Abstrak: Dunia sedang mengalami pandemi Corona Virus Disease 2019 (Covid-19). Penerapan kebijakan Work From Home (WFH) berdampak pada penutupan fasilitas pendidikan, sehingga sekolah dianjurkan untuk belajar dirumah atau Work From Home (WFH). Aplikasi yang digunakan oleh guru untuk memfasilitasi pembelajaran di rumah melalui whatsappdalam smartphone, menimbulkan masalah bagi siswa yang tidak memiliki smartphone. Penelitian ini bertujuan untuk mengetahui dampak kebijakan pemerintah mengenai pembatasan sosial dan kerja di rumah terhadap pendidik dan siswa. Metode yang dilakukan melalui survey menggunakan fasilitas google form. Hasil penelitian menjelaskan bahwa proses pembelajaran harus dilakukan secara daring atau online sesuai anjuran dari pemerintah, meskipun proses pembelajaran tidak dapat terlaksana dengan baik dikarenakan permasalahan teknik seperti penggunaan teknologi yang masih gaptek bagi guru dan terkendalanya koneksi internet dalam proses pembelajaran. Dampak lain yang tergambarkan bahwasannya proses pembelajaran tidak bisa menjangkau secara utuh capaian pembelajaran baik secara kognitif, afektif dan psikomotorik. Dampak corona ini bagi Pendidikan juga akhirnya mengharuskan peran orang tua lebih besar dalam pengawasan dan pembelajaran di Rumah.

Kata Kunci: Analisis anjuran pemerintah; Pelaku pendidikan; Corona virus disease 2019 (covid-19; proses pembelajaran; daring (online) 
Umat manusia sedang berada dalam kesedihan akibat mewabahnya Corona Virus Disease 2019 (Covid-19) yang melanda hampir di seluruh belahan dunia (Mahase, 2020). Penyebaran Corona Virus Disease 2019 (Covid-19) menyebabkan semakin meningkat-nya jumlah kematian, sehingga berdampak pada aspek politik, ekonomi, sosial, budaya, pertahanan, keamanan, dan kesejahteraan masyarakat di Indonesia (PP.RI. No. 21 Thn. 2020). Beberapa negara telah menerapkan kebijakan isolasi yaitu membedakan antara orang sakit dengan penyakit menular dan orang yang tidak terinfeksi (Smith, 2020) yang bertujuan untuk menurunkan penyebaran Covid-19.

Hasil pantauan Unesco menyatakan bahwa lebih dari 188 negara telah menerapkan penutupan nasional pendidikan yang ber-dampak kepada 1.576 .021 .818 siswa (91,3\% dari populasi siswa dunia) (UNESCO, 2020). Pandemi Corona Virus Disease 2019 (Covid-19)mengakibatkan semua siswa di jenjang sekolah dianjurkan untuk belajar di rumah sampai keadaan membaik (Badan Nasional Penanggulangan Bencana, 2020). Penyebaran wabah Covid-19 menuntut seluruh instansi menerapkan kebijakan Work From Home (WFH) dengan menggunakan perangkat aplikasi yang dapat terhubung dengan internet.

Perangkat aplikasi pembelajaran dalam jaringan (daring) membutuhkan berbagai platform yang mudah, murah, dan me-mungkinkan untuk pencapaian tujuan pem-belajaran (Darmalaksana, 2020). Guru melaksanakan pembelajaran kepada siswa secara virtual menggunakan aplikasi whatsapp pada smartphone. Kegiatan pembelajaran dimulai ketika guru memberikan tugas melalui whatsapp kemudian siswa mengumpulkan tugas dalam bentuk gambar/voice note/video. Pembelajaran melalui dalam jaringan (daring) hanya dapat dilakukan bagi siswa yang memiliki smartphone/ laptop, namun tidak semua orang tua siswa mampu meng-operasikan smartphone dan tidak memiliki smartphone.

Kebijakan pembelajaran dalam jaringan (daring) mengakibatkan terjadi gangguan dalam kegiatan pembelajaran oleh guru, siswa, dan orang tua siswa. Pembelajaran dalam jaringan (daring) berdampak pada psikologis siswa dan menurunkan kualitas keterampilan siswa. Beban tersebut merupakan tanggung jawab semua elemen pendidikan dalam memfasilitasi kegiatan pembelajaran bagi semua steakholders pendidikan guna melakukan pembelajaran jarak jauh untuk menekan kerugian dunia pendidikan di masa mendatang (Syah, 2020). Beberapa kelebihan pembelajaran jarak jauh dapat memperluas akses pendidikan untuk masyarakat umum karena struktur penjadwalan yang fleksibel (Setiawan, 2019). Berdasarkan latar belakang kondisi tersebut maka perlu adanya analisis dampak anjuran pemerintah terhadap belajar di rumah.

\section{METODE}

Jenis metode penelitian yang digunakan dalam penelitian ini adalah jenis penelitiankuantitatif survey research. Metode penelitian survei adalah metode penelitian kuantitatif yang digunakan untuk mendapatkan data yang terjadi pada masa lampau atau saat ini, tentang keyakinan, pendapat, karakteristik, perilaku, hubungan variabel dan untuk menguji beberapa hipotesis tentang variabel sosiologis dan psikologis dari sampel yang diambil dari populasi tertentu.

Teknik pengumpulan data melalui penyebaran angket menggunakan lembar kuesioner melalui aplikasi google form dan hasil penelitian cenderung untuk di-generalisasikan (Sugiyono, 2017:8). Sampel dalam penelitian ini adalah 196 pelaku pendidikan yang teridiri dari 61 guru, dan 144 siswa di Jawa Timur. Teknik analisis data yang digunakan dalam penelitian ini adalah dengan teknik analisis deskriptif. Analisis deskriptif adalah statistik yang digunakan untuk menganalisis data dengan cara mendeskripsikan atau menggambarkan data yang telah terkumpul sebagaimana adanya tanpa bermaksud membuat kesimpulan yang berlaku untuk umum atau generalisasi (Sugiyono, 2017:147). 


\section{HASIL DAN PEMBAHASAN}

Pandemi virus Covid-19 menyebabkan semua siswa dijenjang sekolah dianjurkan untuk belajar di rumah. Kebijakan pembatasan sosial dan kerja di rumah atau Work From Home (WFH) berpengaruh terhadap kegiatan pembelajaran. Kegiatan pembelajaran selama pandemi Covid-19 dilakukan melalui dalam jaringan atau online. Kebijakan penerapan pembelajaran dalam jaringan (daring) menimbulkan permasalahan bagi pendidik dan siswa. Kendala dan masalah yang dialami siswa selama pembelajaran di rumah yaitu tugas yang menumpuk, keterbatasan jaringan, dan pembiayaan kuota internet. Kendala dan masalah yang dialami oleh pendidik selama pembelajaran di rumah yaitu menyusun kegiatan pembelajaran yang kreatif dan inovatif agar siswa dapat mencapai target pengetahuan, keterampilan, dan sikap yang dibangun dalam proses belajarnya (Bilfaqih dan Qomarudin, 2015).

Berdasarkan KPAI (2020) menyatakan bahwa siswa mengalami kesulitan selama pembelajaran dalam jaringan (daring) data menghasilkan $77,80 \%$ tugas yang diberikan menumpuk, $42,20 \%$ siswa tidak memiliki kuota, 37,10\% waktu belajar yang sempit, dan 15,60\% tidak memiliki peralatan yang dibutuhkan (misal handphone, Laptop, dll). Pembelajaran dalam jaringan (daring) menyebabkan sulitnya terjadi interaksi antara guru dan siswa, sehingga guru tidak mampu memantau siswa belajar dan beban yang dirasakan oleh siswa semakin berat. Hal ini sesuai dengan data yang dihasilkan oleh KPAI (2020) menyatakan bahwa $73,20 \%$ siswa merasa berat dan $26,80 \%$ siswa merasa tidak berat, sehingga guru harus mampu menciptakan pembelajaran yang kreatif dan inovatif.

\section{Dampak bagi Guru}

Berdasarkan hasil penelitian melalui angket menggunakan fasilitas google form yang disebarkan kepada guru pada tanggal 21 April 2020. Responden yang telah mengisi angket berjumlah 61 guru yaitu 2 guru TK, 10 guru SD/MI, 25 guru SMP/MTS, 18 guru SMA/MA, dan 6 guru SMK. Hasil angket menyatakan bahwa $44,4 \%$ sangat setuju dan $48,1 \%$ setuju terkait pembatasan sosial dan kerja di rumah akibat pandemi Covid-19 (Gambar 1). Namun kebijakan tersebut membuat guru tidak mampu mencapai target materi yang telah disusun dalam Program Semester (Promes). Program Semester yang berfungsi untuk mengetahui beban materi dalam satu semester (Permendikbud, 2016). Penerapan pembelajaran dalam jaringan (daring) mengakibatkan proses pembelajaran terhambat karena beberapa guru senior tidak mampu mengaplikasikan internet atau gagap teknologi. Maka perlu adanya pendampingan dan pelatihan pembelajaran melalui dalam jaringan (daring) (Purwanto, et al., 2020). Selama pandemi Covid-19 proses pembelajaran berlangsung secara searah, sehingga siswa dan guru dapat menggunakan fasilitas palfform e-learning seperti Ruang Guru, Google Clasroom, Google Meet, dan Zoom.

Pembelajaran dalam jaringan (daring) di tengah pandemi Covid-19 hendaknya mampu memfasilitasi pengalaman belajar siswa, namun pembelajaran dalam jaringan (daring) saat ini guru hanya memberikan tugas kepada siswa untuk dikerjakan (Bilfaqih dan Qomarudin, 2015). Berdasarkan survei KPAI (2020) terdapat 76,6\% siswa tidak senang dengan pembelajaran dalam jaringan (daring) di rumah. Kesulitan belajar siswa berasal dari tugas yang menumpuk dan tidak memiliki kuota internet. Hal ini sesuai dengan pernyataan dari Ibu Martuhani usia 45 Tahun seorang guru SD/MI menyatakan bahwa pembelajaran dalam jaringan (daring) dilakukan dengan memberikan tugas melalui grup whatsapp wali murid yang bertujuan untuk memberikan aktivitas siswa di rumah. Pemberian tugas yang menumpuk dapat diganti dengan pembuatan karya berupa lagu, puisi, essay, dan karya tulis mengenai Covid-19. Berdasarkan kompas.com menyatakan bahwa pembelajaran dalam jaringan (daring) dapat dilakukan dengan memberikan ilmu mengenai penyebaran Covid-19 misalnya gejala yang timbul akibat Covid-19, isolasi mandiri selama 14 hari, sehingga kegiatan tersebut mampu menekan penyebaran Covid-19 dan meningkatkan keperdulian sosial. 


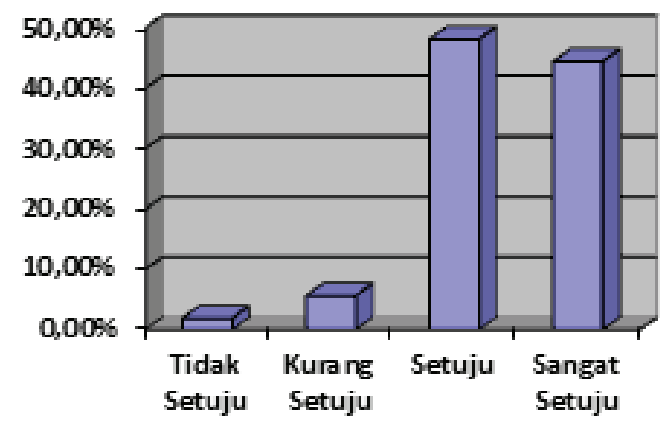

Gambar 1. Pelaksanaan pembatasan sosial dan kerja di rumah (WFH) pihak Guru

Berdasarkan angket pada pertanyaan terkait pembelajaran berbasis kehidupan (contectual learning) melalui pembelajaran dalam jaringan (daring) hasil menyatakan 22,2\% sangat setuju dan 22,2\% kurang setuju (Gambar 2). Hal ini disebabkan pembelajaran berbasis kehidupan bertujuan untuk mengarahkan siswa untuk menjadi pribadi yang utuh, sehingga mampu memecahkan masalah dan menjalani kehidupan secara berimbang (Hambali, 2017). Pembelajaran berbasis kehidupan paling banyak pada jenjang pendidikan Sekolah Dasar (SD), sehingga guru SD/MI harus mampu mengaitkan pembelajaran dengan kehidupan sehari-hari (Rohman dan Asmaranty, 2019). Selama pandemi Covid-19 pembelajaran berbasis kehidupan (contectual learning) dapat dilaksanakan melalui ilustrasi pencegahan Covid-19 dengan memberikan tontonan edukasi. Pembelajaran berbasis kehidupan juga dapat dilakukan dengan memberikan permasalahan di kehidupan nyata.

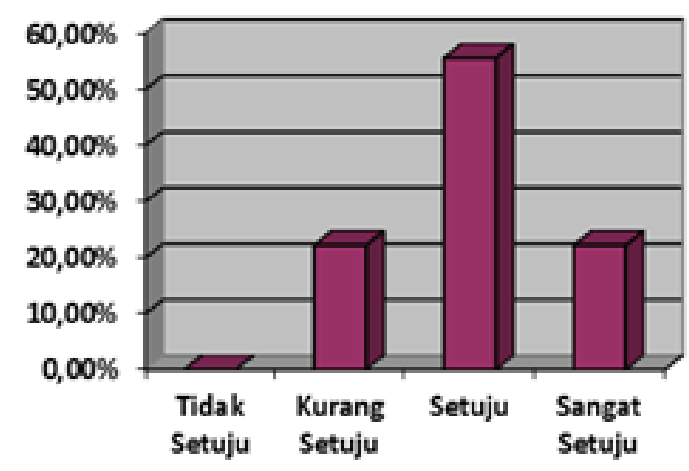

Gambar 2. Pembelajaran berbasis kehidupan (contectual learning) melalui pembelajaran dalam jaringan (daring)

Berdasarkan angket pada pertanyaan apakah efektif dan efisien proses pembelajaran dalam jaringan (daring) hasil menyatakan bahwa 48,1\% guru merasa pembelajaran dalam jaringan (daring) kurang efektif dan efisien digunakan (Gambar 3). Hal ini sesuai dengan pernyataan Ibu Erwinda usia 43 Tahun mengajar SMP/MTS menyatakan bahwa pembelajaran dalam jaringan (daring) menyebabkan guru tidak bisa mengajar sesuai jadwal, tidak mampu mengetahui kondisi siswa, dan tidak mampu memberikan pelayanan khusus kepada siswa yang terlambat dan terhambat dalam belajar. Ibu Farida usia 45 Tahun mengajar SMA/MA menyatakan bahwa pembelajaran dalam jaringan (daring) menghambat proses interaksi antara siswa dan guru, sehingga guru tidak mampu memfasilitasi pembelajaran seperti kegiatan pembelajaran yang dilakukan di kelas. Pembelajaran dalam jaringan (daring) di tengah pandemi Covid-19 tidak difasilitasi dengan aplikasi yang memadai dan pemberian kuota gratis bagi guru dan siswa (Purwanto, et al., 2020). Fasilitas yang memadai mampu meningkatkan hasil belajar dan keterampilan siswa (Bilfaqih dan Qomarudin, 2015). 


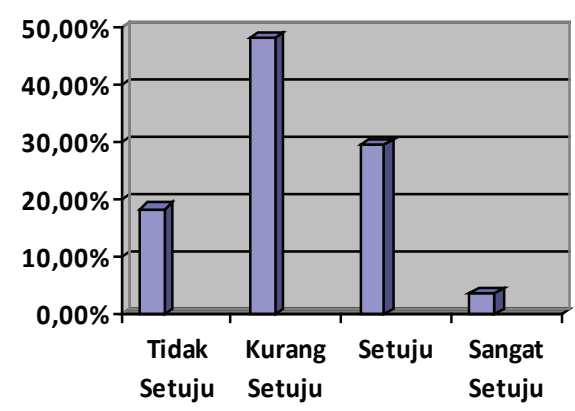

Gambar 3. Efektif dan efisien proses pembelajaran dalam jaringan (daring)

Berdasarkan angket pada pertanyaan apakah pembelajaran dalam jaringan (daring) memberikan kemudahan kepada Bapak/Ibu dalam menyampaikan materi hasil menyatakan bahwa 31,5\% kurang setuju dan 42,6\% sangat setuju pembelajaran dilakukan secara dalam jaringan (daring) (Gambar 4). Hal ini diakibatkan beberapa guru merasa kesulitan dalam menyampaikan materi kepada siswa seperti yang dialami oleh Ibu Sukma usia 33 Tahun mengajar SMP/MTS menyatakan bahwa pembelajaran dalam jaringan (daring) memberikan kesulitan dalam menjelaskan materi matematika, sehingga Ibu Sukma melakukan shooting video pembelajaran kemudian dishare kepada siswa melalui grup whatsapp. Ibu Amalia mengajar SMA/MA merasa kesulitan dalam menyampaikan materi matematika. Maka perlu adanya alternatif yang dilakukan oleh pemerintah untuk memberikan fasilitas aplikasi bagi guru matematika, fisika, dan kimia yang membutuhkan penjelasan mengenai penerapan rumus. Berdasarkan cnn.com proses pembelajaran pada mata pelajaran berhitung dapat dilakukan melalui powerpoint dan google meet tetapi kendalanya tidak semua siswa mampu mengakses karena tidak memiliki handphone dan orang tua yang gagap teknologi.

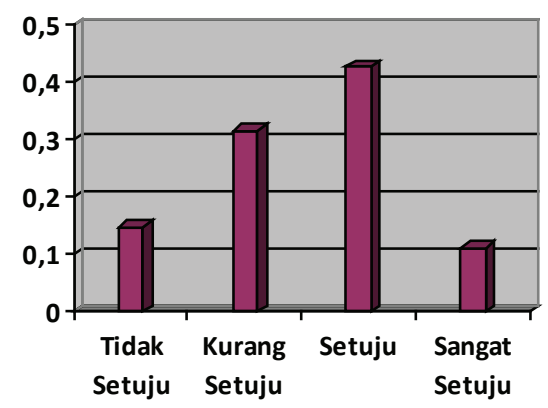

Gambar 4. Pembelajaran dalam jaringan (daring) memberikan kemudahan dalam menyampaikan materi

Berdasarkan angket pada pertanyaan apakah selama proses pembelajaran dalam jaringan (daring) Bapak/Ibu mengalami keluhan dari orang tua siswa hasil menyatakan bahwa 51,9\% setuju (Gambar 5). Hal ini ditunjukkan dengan data 45 guru mendapatkan keluhan dari wali murid atau orang tua siswa akibat pembelajaran dalam jaringan (daring) selama pandemi Covid-19. Kendala yang dihadapi para guru yaitu adanya penambahan biaya pembelian kuota internet, memerlukan koneksi jaringan ke internet dan kuota oleh karena itu tingkat penggunaaan kuota internet akan bertambah dan akan menambah beban pengeluaran guru dan siswa. Hal ini sesuai dengan pernyataan Bapak Farid Hidayat usia 39 Tahun mengajar SD/MI menyatakan bahwa pemerintah harus memberikan kuota internet gratis dan menyediakan halaman/web yang dapat diakses secara gratis bagi guru dan siswa sebagai fasilitas belajar-mengajar. Bapak Suliadi usia 43 Tahun mengajar SMP/MTS mendapatkan keluhan dari orang tua siswa karena pembelajaran yang dilakukan menghabiskan banyak kuota dan sebagian orang tua siswa tidak bisa bekerja karena kebijakan Work From Home (WFH). 


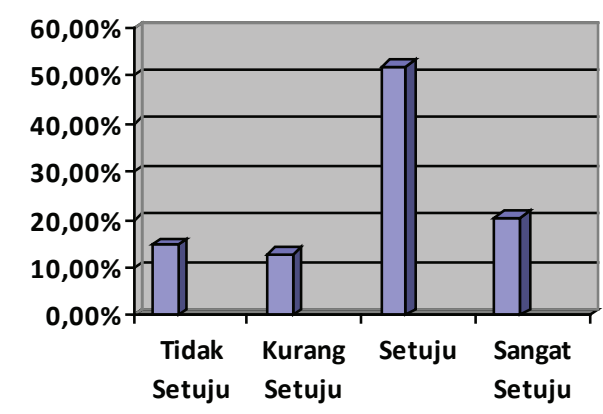

Gambar 5. Bapak/Ibu guru mendapat keluhan dari Orang tua siswa dalam pembalajaran jaringan (daring)

\section{Dampak bagi Siswa}

Berdasarkan hasil penelitian melalui angket menggunakan fasilitas google form yang disebarkan kepada siswa pada tanggal 21 April 2020. Responden yang telah mengisi angket berjumlah 144 siswa yaitu 8 siswa SD/MI, 67 siswa SMP/MTS, 60 siswa SMA/MA, dan 9 siswa SMK. Hasil angket menyatakan bahwa 39,9\% setuju dan 43,4\% sangat setuju (Gambar 6) terkait anjuran pemerintah mengenai pembatasan sosial dan kerja di rumah aja. Dampak wabah Covid-19 menyebabkan pembelajaran dilakukan secara online atau dalam jaringan (daring), sehingga siswa melakukan aktivitas belajar menggunakan fasilitas smartphone dan laptop. Pembelajaran dalam jaringan (daring) mengakibatkan siswa harus melakukan pendalaman materi secara mandiri, hal ini disebabkan karena guru tidak mampu memberikan pengawasan secara langsung. I Made seorang pelajar SMA/MA menyatakan bahwa pembelajaran dalam jaringan (daring) menghambat proses mengingat materi karena pembelajaran berlangsung hanya sekedar chatting. Menurut Syarifah (2015) menyatakan bahwa terdapat beberapa siswa yang tidak mampu menggali sendiri pengetahuannya, sehingga guru harus memiliki keterampilan menjelaskan agar mampu memfasilitasi pengetahuan siswa.

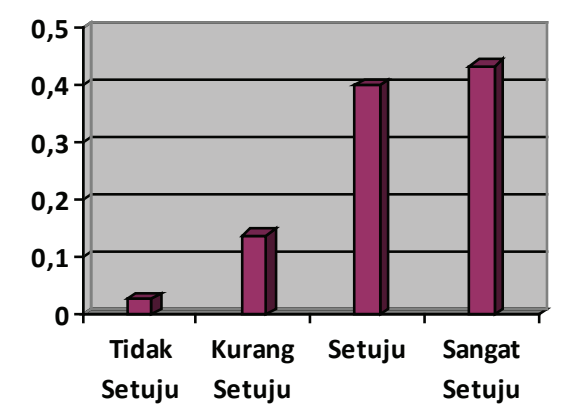

Gambar 5. Bapak/Ibu guru mendapat keluhan dari Orang tua siswa dalam pembalajaran jaringan (daring)

Berdasarkan angket pada pertanyaan apakah efektif dan efisien proses pembelajaran dalam jaringan (daring) hasil menyatakan bahwa 53,8\% kurang setuju dan 9,8\% tidak setuju (Gambar 7). Pembelajaran dalam jaringan (daring) selama pandemi Covid-19 hanya berlangsung satu arah. Guru hanya memberikan tugas melalui fasilitas whatsapp dengan memberikan rentang waktu pengerjaan. Hal ini bertentangan dengan karakteristik pembelajaran kurikulum 2013 revisi yang menyatakan bahwa pembelajaran harus berlangsung secara dua arah dan multiarah (Permendikbud, 2016). Urvia seorang pelajar SMA/MA menyatakan bahwa mereka males mengerjakan tugas, tidak mampu berkonsentrasi penuh karena ketika pembelajaran menggunakan smartphone dia lebih tertarik bermain sosial media (sosmed). Pembelajaran daring (daring) mengakibatkan siswa terus bersinggungan dengan smartphone dan laptop, sehingga akan menimbulkan efek samping kecanduan dalam memegang gadget. Maka peran orang tua penting sebagai pendamping siswa semasa pembelajaran dalam jaringan (daring). 


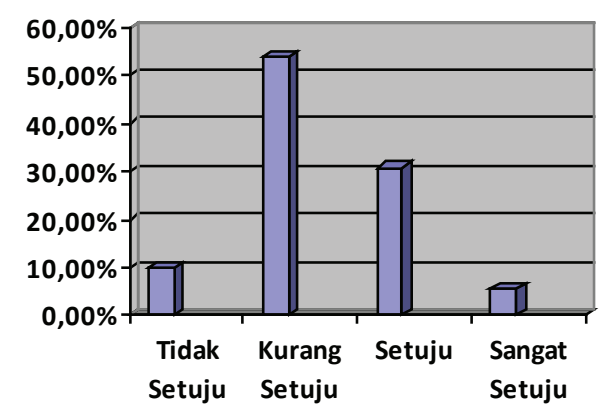

Gambar 7. Efektif dan efisien proses pembelajaran dalam jaringan (daring)

Berdasarkan hasil angket pada pertanyaan apakah tugas yang diberikan kepada oleh Bapak/Ibu guru mampu memfasilitasi kalian dalam memahami materi menghasilkan bahwa 32,2\% setuju dan 49,7\% kurang setuju (Gambar 8). Hal ini disebabkan karena pembelajaran dalam jaring (daring) yang dilakukan oleh guru selama wabah Covid-19 yaitu memberikan banyak tugas kepada siswa. Hal ini sesuai dengan pernyataan Sendy seorang pelajar SMP/MTS menyatakan bahwa tidak menyukai pembelajaran daring karena tugas yang diberikan oleh guru semakin banyak. Pemberian tugas rumah menjadi strategi guru dalam meningkatkan prestasi belajar siswa. Hal ini dimaksudkan agar siswa belajar di luar jam sekolah dengan mengerjakan tugas rumah yang diberikan oleh guru tetapi tugas rumah yang terlalu banyak akan menurunkan minat belajar siswa. Retno dalam siaran pers (2020) menyatakan bahwa para guru memahami home learning adalah dengan memberikan tugas secara online, sehingga para siswa dan orang tua mengeluh. Republika.com (2020) menyatakan bahwa pembelajaran dalam jaringan (daring) di tengah pandemi Covid-19 guru memberikan aktivitas belajar rutin pada siswa agar tetap belajar di rumah. Aktivitas belajar yang dilakukan siswa di rumah dimaksudkan agar menjaga semangat belajar siswa ketika sekolah masuk kembali.

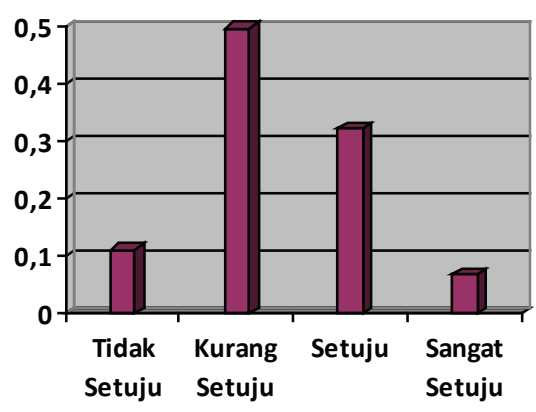

Gambar 8. Fasilitas pembelajaran dalam jaringan (daring) memberikan kemudahan siswa dalam memahami materi

\section{SIMPULAN DAN SARAN}

\section{Simpulan}

Berdasarkan hasil dan pembahasan di atas, dapat diambil kesimpulan bahwa pelaku Pendidikan ikut terdampak kasus pandemi corona, para pelaku Pendidikan harus belajar dan bekerja di rumah sesuai dengan protokol dan anjuran oleh pemerintah. Proses belajar dan bekerja di rumah dilakukan dengan proses daring atau online. Kegiatan tersebut memberikan dampak positif terhadap penekanan penyebaran virus corona dan terdapat dampak negatif bagi Pendidikan yaitu proses pembelajaran yang sedikit terganggu terhadap mekanisme dan pola Pendidikan

\section{Saran}

Saran terkait dampak corona bagi pelaku Pendidikan yang perlu diperhatikan dapat dijelaskan sebagai berikut. Pemerintah pusat dimana disini yang dimaksud Kementerian Pendidikan dan Kebudayaan untuk melakukan regulasi Pendidikan untuk mengatasi permasalahan tersebut serta memberikan kewenangan 
kepada satuan Pendidikan agar dapat mealokasikan dana Pendidikan untuk proses pembelajaran yang bersifat daring.

\section{DAFTAR RUJUKAN}

Badan Nasional Penanggulangan Bencana. (2020). Keputusan Kepala Badan Nasional Penanggulangan Bencana Nomor 13 A Tahun 2020 Tentang Perpanjangan Status Keadaan Tertentu Darurat Bencana Wabah Penyakit Akibat Virus Corona Di Indonesia.

Bilfaqih \& Qomarudin. (2015). Esensi Pengembangan Pembelajaran Daring. Yogyakarta; deepublish. ISBN 978-Nomor ISBN.

Consumer News and Business Channel Indonesia. (2020). Corona, Kelas Daring, Curhat 2 Guru untuk Orang Tua : A Transmedia Company. Dari https://m.cnnindonesia.com/gaya-hidup/20200330165053-284-488368/ corona-kelas-daring-dan-curhat-2-guru-untuk-orang-tua

Darmalaksana, W. (2020). Fakultas Ushuluddin UIN Sunan Gunung Djati Bandung 24 Maret 2020. 2020, 1-5.

Hambali, M. (2017). Pembelajaran Berbasis Kehidupan: Konsep Dan Implementasinya Dalam Pembelajaran Bahasa Indonesia. Waskita. Vol. 1, No. 1, 2017.

Huang, R. H., Liu, D. J., Tlili, A., Yang, J. F., \& Wang, H. H. (2020). Handbook on facilitating flexible learning during educational disruption: The Chinese experience in maintaining undisrupted learning in COVID-19 Outbreak. In Smart Learning Institute of Beijing Normal University UNESCO (pp. 1-54). https://iite.unesco. org/news/handbook-on-facilitating-flexible-learning-during-educational-disruption/

Irawan, H. (2020). Inovasi Pendidikan Sebagai Antisipasi Penyebaran Covid-19. https://ombudsman.go.id/ artikel/r/artikel--inovasi-pendidikan-sebagai-antisipasi-penyebaran-covid-19

Komisi Perlindungan Anak Indonesia (KPAI). (2020). Guru Tak Boleh Bebankan Tugas di Luar Kemampuan Siswa. (online) https: //news.detik.c om/berita/d-4993866/kemendikbud-guru-tak-boleh-bebankan-tugas-diluar-kemampuan-siswa?_ga=2.57169258.1117432155.1589810068-177998992.1488448910.

Komisi Perlindungan Anak Indonesia (KPAI). (2020). Siswa Keluhkan Tugas Menumpuk. (online) https://news. detik.com/berita/d-4992921/ada-246-aduan-di-kpai-soal-belajar-daring-siswa-keluhkan-tugas-menumpukkuota ?ga $=2.53507560 .1117432155 .1589810068-177998992.1488448910$

Mahase, E. (2020). Coronavirus covid-19 has killed more people than SARS and MERS combined, despite lower case fatality rate. BMJ (Clinical Research Ed.), 368(February), m641. https://doi.org/10.1136/bmj.m641

Peraturan Menteri Pendidikan dan Kebudayaan No. 20 Tahun 2016 tentang Standar Kompetensi Kelulusan Pendidikan Dasar dan Menengah. (online).(https://bsnpindonesia.org/wpcontent/uploads/2009/04/ Permendikbud_Tahun2016_Nomor020_Lampiran.pdf), diakses 20 Oktober 2019.

Peraturan Menteri Pendidikan dan Kebudayaan No. 21 Tahun 2016 tentang Standar Isi Pendidikan Dasar Dan Menengah. (online). (http://bsnp-indonesia.org/wpcontent/uploads/2009/06/Permendikbud_Tahun2016_ Nomor021_Lampiran.pdf), diakses 20 Oktober 2019.

Peraturan Menteri Pendidikan dan Kebudayaan No. 22 Tahun 2016 tentang Standar Proses Pendidikan Dasar Dan Menengah. (online). (http://bsnp-indonesia.org/wpcontent/uploads/2009/06/Permendikbud_Tahun2016_ Nomor022.pdf), diakses 20 Oktober 2019.

Purwanto, A., Asbari, M., Pramono, R., \& Santoso, P. (2020). Studi Eksploratif Dampak Pandemi COVID-19 Terhadap Proses Pembelajaran Online di Sekolah Dasar. Journal of Education, Psychology and Counseling (EduPsyCouns). Volume 2 Nomor 1 (2020) ISSN Online : 2716-4446.

Rohman \& Asmaranty. (2019). Pembelajaran Berbasis Kehidupan Dengan Muatan Karakter Bangsa Untuk Pembelajaran Bahasa Indonesia Abad 21. Kongres Bahasa Indonesia.

Setiawan, A. R. (2019). Lembar Kegiatan Siswa untuk Pembelajaran Jarak Jauh Berdasarkan Literasi Saintifik pada Topik Penyakit Coronavirus 2019 (COVID-19). Indo American Journal of Pharmaceutical Sciences, 23(3), 6. https://doi.org/10.5281/zenodo.1477753

Smith, W. (2020). Isolation, quarantine, social distancing and community containment.

Sugiyono. (2017). Metode Penelitian Kuantitatif, Kualitatif, dan $R \& D$.

Syah, R. (2020). Dampak Covid-19 pada Pendidikan di Indonesia: Sekolah, Keterampilan, dan Proses Pembelajaran. Sosial Dan Budaya Syar-I. https://doi.org/https://doi.org/10.15408/sjsbs.v7i5.15314

Syarifah. (2015). Kemampuan Guru Menjelaskan Dalam Pembelajaran Tematik Berbasis KTSP di SD Kecamatan Ngaliyan Kota Semarang: Skripsi Tidak Diterbitkan: UNNES.

UNESCO. (2020). 290 million students out of school due to COVID-19: UNESCO releases first global numbers and mobilizes response. 